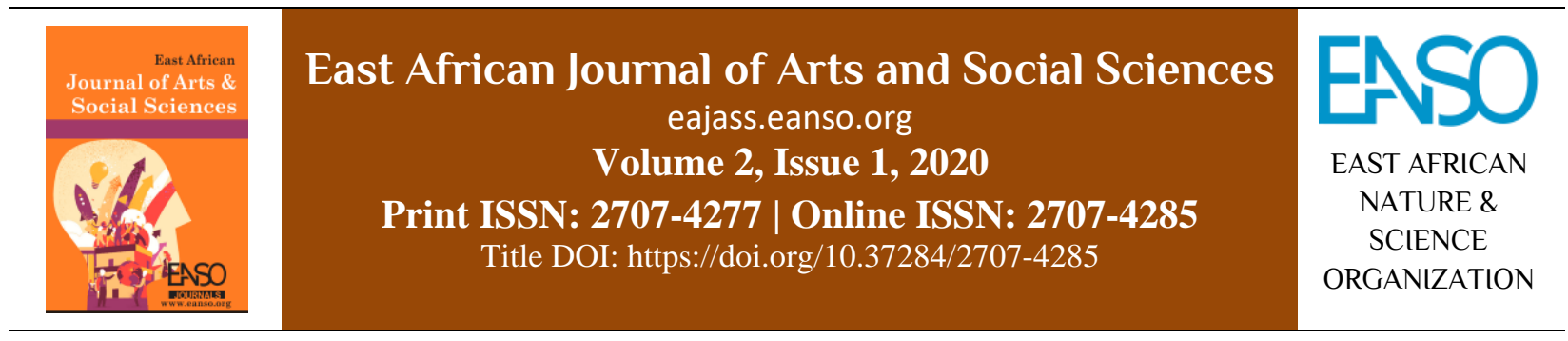

Original Article

\title{
Determination of Prominent Representations of Domestic Products Advertisements in Kass TV on to Kipsigis Consumer in Belgut Sub-County, Kericho, Kenya
}

\author{
Judith Chepchirchir \\ University of Kabianga, P. O. Box 2030 - 20200, Kericho, Kenya. \\ *Correspondence email: judithchirry87@gmail.com.
}

Article DOI: https://doi.org/10.37284/eajass.2.1.130

Article history:

Received: 26 Feb 2020

Accepted: 11 Mar 2020

Published: 06 Apr 2020

Keywords:

Multimodal Discourse

Analysis,

Kass Tv,

Advertisement,

Consumer Choices,

Modes of

Communication.

\section{ABSTRACT}

Commercial advertising is part and parcel of our day to day lives which bears vast meanings, thus drawing a great discussion. This study, therefore, intended to study television (TV) advertisements. Television advertisements come in both visual and verbal modes of communication. Meaning is achieved by sounds and images which in turn influence the viewers' choice. This study sought to investigate how adverts in Kass TV use music, textual and visual images to create meaning and its influence on Kipsigis consumers. The objective of this study was to: determine the prominent representations of domestic products by Kass TV to Kipsigis consumer in Belgut sub-county, Kericho, Kenya. To establish if the prominent representations of domestic products in Kass TV influence consumer choice within Belgut sub-county and to evaluate the extent to which the prominent representations of domestic products reflect the sociocultural context of Kenya as far as Belgut Sub-County is considered. The study used Kress and van Leeuwen's Multimodal Discourse Analysis theory, the theory of semiotics and information processing theory. 'Multimodality' typically refers to the use of both verbal and non-verbal modes of communication. This study, therefore, analysed the verbal and visual modes of communication in TV advertisements in order to determine their influence on Kipsigis consumers. A descriptive survey research design was adopted. The target population was Kass TV viewers in Belgut sub-county because it is among the Kass TV coverage areas and also due to the fact that a wide population in the sub-county is Kipsigis speakers. Simple random sampling was used to identify the respondents. A structured questionnaire which was selfadministered to the Kass TV viewers and buyers of the advertised domestic 
products was used. 186 respondents were sampled. Data was analysed using content analysis with the use of Frith's table for analysis of layers of meanings (surface meaning, advertiser's intended meaning and cultural meaning) by employing descriptive statistics. The study was aimed at contributing to the studies of Multimodal Discourse Analysis (MDA) since it sought to analyse how information is presented in Kass TV advertisement of domestic products. It also aimed at shedding more light on letting consumers be aware of the multiple modes that TV producers of television advertisement use to influence their buying behaviour. Television adverts were found to blend visual and verbal modes of communication.

\begin{abstract}
APA CITATION
Chepchirchir, J. (2020). Determination of Prominent Representations of Domestic Products Advertisements in Kass TV on to Kipsigis Consumer in Belgut Sub-County, Kericho, Kenya. East African Journal of Arts and Social Sciences, 2(1), 8-14. https://doi.org/10.37284/eajass.2.1.130
\end{abstract}

\title{
CHICAGO CITATION
}

Chepchirchir, Judith. 2020. "Determination of Prominent Representations of Domestic Products Advertisements in Kass TV on to Kipsigis Consumer in Belgut Sub-County, Kericho, Kenya". East African Journal of Arts and Social Sciences 2 (1), 8-14. https://doi.org/10.37284/eajass.2.1.130.

\section{HARVARD CITATION}

Chepchirchir, J. (2020) "Determination of Prominent Representations of Domestic Products Advertisements in Kass TV on to Kipsigis Consumer in Belgut Sub-County, Kericho, Kenya”, East African Journal of Arts and Social Sciences, 2(1), pp. 8-14. doi: 10.37284/eajass.2.1.130.

\section{IEEE CITATION}

J. Chepchirchir, "Determination of Prominent Representations of Domestic Products Advertisements in Kass TV on to Kipsigis Consumer in Belgut Sub-County, Kericho, Kenya", EAJASS, vol. 2, no. 1, pp. 8-14, Apr. 2020.

\section{MLA CITATION}

Chepchirchir, J. "Determination of Prominent Representations of Domestic Products Advertisements in Kass TV on to Kipsigis Consumer in Belgut Sub-County, Kericho, Kenya". East African Journal of Arts and Social Sciences, Vol. 2, no. 1, Apr. 2020, pp. 8-14, doi:10.37284/eajass.2.1.130.

\section{INTRODUCTION}

The influence of advertisements on the advert viewer or reader is a great subject worth to be discussed (Cashmore, 2008). Media has been recognised and proved as a very powerful and influential force in shaping the perception and purchase intentions as well as behaviours of masses. Images used in both print and electronic media tend to be so powerful. Visual images, therefore, play a crucial role in influencing consumer choice of products. This is because images arouse the viewer's emotions and attitude towards the advert. Adverts become memorable to the viewer if they are well packaged.

Advertising is a means of marketing used by companies to create awareness to the target audience about a new product or to keep them reminded of the existing products and persuade them to purchase those products or services. Advertisers, therefore, find it difficult when choosing the means that will present their messages effectively (Kotler \& Keller, 2009). Television and the internet or online advertising are the most current channels of marketing used in developed and developing countries. It is important for the consumers of services provided by the two companies to be aware of and access all the important information about the products offered by the two companies before making purchase decisions. When consumers become aware of how adverts are presented in order to manipulate them, they will be able to make the best brand choices. Bateman (2014) posits that it is through advertising that consumers become aware of the available 
goods and services in the market. The main aim of advertising is to create awareness on prospective buyers and to let them develop a positive attitude towards the products or services thus causing them to purchase those products or services. Companies continue paying for advertisements to ensure that they keep their customers and even attract more to consume their products. In doing this, organisations should be aware of the elements of presentations in their adverts that make prospective consumers behave differently.

The main aim of advertising is to let the viewer be aware of the product, persuade them to buy the product and thus maximising the profit of the company. Cook (2001) posits that advertising messages should be beautifully packaged so as to attract the viewer's attention and should be strategically placed in order to stick in the viewer's memory. Bateman (2014) states that advertising through the mass media especially television; greatly promotes sales. This study, therefore, intended to analyse the prominent ways information is presented in TV advertisements in order to influence the consumer.

Nanjom (2002) perceives advertising as a way of basically letting prospective buyers aware of the product or service. Kotler (2009) views advertising as a tool for persuading potential buyers and creating awareness about the product or service. To Kotler, advertising should make the reader or viewer respond positively and become loyal to the brand. Advertising gives organisations a chance of blending their messages in a way that their products become outstanding from others. As a result, making the potential buyers develop an interest in the advert and buy the product (Hazel, 2007). Kelly-Holmes (2005) argues that media images make consumers think about a brand continuously. Images, therefore, influence the attitude of the viewer towards the product. Further, Rossiter and Percy (1987) state that images in advertisements are very important because they help the viewer identify the product from others. They also make the advert stick in the viewer's mind thus becoming memorable.

Representation of media images in creating awareness among the viewers is, therefore, critical. Development of media images should be done effectively in order to affect consumer's buying behaviour positively thus increasing sales (Hassan, 2015). Therefore, if a media image portrays any elements that are not a representation of the target audience; it will most likely have less impact on the minds of the consumer. With knowledge about the social-cultural elements of the target audience, organisations will tend to present their products and services effectively thus embracing acceptability. Prahald, Martin and Unsworth (2013) confirm the shift from promotion to representation. Words and pictures used in the adverts combine to convey meaning. For an effective interpretation to occur, the two should be packaged wisely. The colours used in the pictures should be as attractive as possible and the words should reinforce the product.

Although multimodal texts are used in diverse contexts such as classroom discourse, sports, and political discourse, among others; they are becoming increasingly popular for television advertising. Gillespie and Halford (2006) used multimodality in classroom discourse to discuss the effectiveness of using computer-aided materials in class to raise students' interest. The effect of multimodality in society with a focus on psychology and sociolinguistics has been discussed by Connoly (2002). Barthes (1977) and Williamson (1972) become the early scholars to use semiosis to examine the language used in advertisements. Barthes (1977) discussed how pictures and texts relate to advertisements while Williamson (1978) believes the analysis of advertisements is more than just coding and decoding. Vestergaard and Schroder (1985) explained that through advertising, text producers socially interact with the viewer.

This study intended to examine the advertisement of domestic products among the Kass television viewers in Belgut Sub-County within Kericho County in Kenya. Kass Television is a vernacular commercial television station owned and operated by Kass Media Group which also owns Kass FM, a vernacular radio station and Kass Magazine. Kass TV was founded in March 2010. Kass TV broadcasts in the Kalenjin language. The channel was created as a response to a request by Kass FM's radio followers in Rift Valley and Diaspora. It broadcasts in the following regions Nairobi and its environs including, Machakos, Thika, Kiambu and 
Limuru; Rift-valley province which include: Nakuru, Eldoret, Kitale, Baringo, Kapenguria, Timboroa, Gilgil, Naivasha, Bomet, and Kericho; Coastal region which includes Mombasa, Malindi, Mtwapa, Changamwe, Ukunda and Kilifi. It also broadcasts in parts of Western and Nyanza which include Kakamega, Kisumu, and Kisii and internationally in Washington DC, USA.

'Kass' means 'listen' as per the Kalenjin community, which lives in the Rift valley of Kenya. They use the slogan 'Kimnatet naet' meaning 'Knowledge is power'. Its mission is to become a leading TV broadcaster in the Kalenjin language. It's committed to effective broadcasting of services to its audience, customers and the public. The channel aims at making use of innovation and technology to provide quality services, ensuring that information is disseminated to all without bias by airing programmes that are economically, educationally, culturally and socially rich thus improving on the welfare of Kipsigis and Kenyans at large. Kass TV provides programmes including news, interactive stories, entertainment, features, comedies, drama shows and soap operas all broadcasting in Kalenjin language. It caters to the burgeoning vernacular TV audience that has grown as a result of the digital migration in Kenya. Kass TV is broadcasted on Zuku TV channel 019 and it is also hosted by Multi-choice on both DSTV channel 266 and Go TV channel 99 (Wamathai, 2016).

Images in TV adverts provide the channel for communicating visual content. With the use of colours, slogans and music, images gain more appealing qualities than using just language. A combination of image and text offers detailed information to the viewer of a TV advert. Music also can influence the viewer towards purchasing the product (Wang, 2007).

\section{LITERATURE REVIEW}

Local and international advertisers have continuously struggled in trying to choose the best language at which they can communicate effectively to their target audiences (Machin, 2007). Vernacular TV channels are mushrooming in the current Kenyan media with the aim of educating and informing the general public. They use vernacular languages that the local audience understands best. Kass TV is a commercial TV channel is also used by companies to advertise and promote their products or services to the rural population. Advertisers should, therefore, bear in mind about the factors that determine the target audience's buying behaviour. These include language, social (music, colour, and design), economic, political and cultural aspects of life. Advertisers are often therefore required to make standardisation versus localisation decisions after conducting a cost-benefit analysis of each situation (Machin, 2007).

There exists little research in Kenya on the relationship between language choice and advertising effectiveness. Consumers also have little understanding of the underlying meanings behind the visual and non-visual ways of communications that advertisers use to manipulate them. This study, therefore, examined the use of verbal and visual modes of communication used in television advertisements and its influence on the consumer choice of domestic products on Kass TV Kenyan viewers.

\section{Multimodal Discourse Analysis}

Barthes being the earliest scholar to study multimodal discourse, discussed how both language and images interact to create meaning. In 1990's multimodal metaphor approach and Systemic Functional Linguistics (SFL) approach were applied widely applied in linguistic researches. Forceville (1996) represents a multimodal metaphor approach as a study that focuses on the use of multiple modes of communication to achieve meaning effectively. Halliday (1994) represents Systemic Functional Linguistics as a study of the relationship between language and social structure. Kress and van Leeuwen (2006) drew their theoretical contributions from Halliday's SFL. Using varied research methods, MDA has been a great subject for research. Stenglin and Ventola (2011) studied multimodality in three-dimensional spaces. Hood (2011) studied the verbal and non-verbal features of MDA while O'Halloran (2012) studied the meanings behind the use of pictures and comic materials. Previous studies have shown that there's a great use of MDA in media. 


\section{Visual Grammar}

The framework of visual grammar as proposed by Kress and van Leeuwen (2006) attempts to analyse linguistic texts. They draw their illustrations from Halliday's former semiotic finding which argues that visual texts perform three meta-functions namely interpersonal function, ideational function and textual function. Kress \& van Leeuwen (2006) used representational instead of ideational, interactive instead of interpersonal and compositional instead of textual.

\section{METHODOLOGY AD MATERIALS}

\section{Sample Size and Sampling Procedures}

Advertisements featured on Kass TV were sampled for content analysis. It helped to determine which advertisements were based on domestic products. The researcher used simple random sampling to aid in the selection of respondents to fill the questionnaires. The researcher randomly sampled viewers and shoppers of Kass TV and shoppers of the domestic adverts featured in Kass TV. They answered a self- administered questionnaire set in the English language to access their views on Kass TV commercials of domestic products. The research used stratified sampling to get a sample of 187 respondents and Kass television advertisements and a related questionnaire was selfadministered to collect data for analysis.

The following formula by Yamane's (1967) was applied to determine the sample size. The formula is as given below.

$\mathrm{n}=\mathrm{N} / 1+\mathrm{N}(\mathrm{e})^{2}$

$\mathrm{n}=350 / 1+350(0.05)^{2}=187$

Where; N- Population $=350$,

$\varepsilon-$ Error margin $=0.05=5 \%$,

the population $=187 / 350=0.53$

\section{RESULTS AND DISCUSSIONS}

Out of 170 participants who filled and returned the questionnaires, 90(53\%) were female while 80 $(47 \%)$ were male. Gender of the respondents is important because it guided in further analysis of the response; for instance, findings showed that the number of males and females who perceived that the use of certain colours in the TV adverts influences their buying behaviour. Findings of the study indicated that there exists a positive relation between TV advertising and consumer choice.

The distribution of the age of the respondents was considered in order to determine if age has an impact on consumer choices.

Table 1: Responses Based on the Age of the Participants

\begin{tabular}{lll}
\hline $\begin{array}{l}\text { TV viewer's } \\
\text { age }\end{array}$ & $\begin{array}{l}\text { Frequency } \\
(\mathbf{f})\end{array}$ & $\begin{array}{l}\text { Percentage } \\
(\boldsymbol{\%})\end{array}$ \\
\hline $15-20$ & 20 & 11.8 \\
$21-30$ & 50 & 29.4 \\
$31-40$ & 70 & 41.2 \\
Above 40 & 30 & 17.6 \\
Total & $\mathbf{1 7 0}$ & $\mathbf{1 0 0}$ \\
\hline
\end{tabular}

According to Table 1Table 1: Responses Based on the Age of the Participants, majority of the respondents (70) were aged 31-40 years followed by those of age bracket (21-30), then those of age bracket (40 and above) at $17 \%$, while respondents at the age bracket of up to 20 were the least at $11 \%$. Findings of the study showed that adults of age (3140) strongly believed that television adverts have considerable influence on their purchase making.

Table 2: Responses on the Impact of Prominent Representations in Television Advertising

\begin{tabular}{lll}
\hline Aspects & $\begin{array}{l}\text { Frequency } \\
\text { (f) }\end{array}$ & $\begin{array}{l}\text { Percentage } \\
(\mathbf{\%})\end{array}$ \\
\hline Colour & 80 & $47.0 \%$ \\
Background music & 50 & $29.4 \%$ \\
Photography/image & 20 & $11.8 \%$ \\
Celebrity appearance & 15 & $8.9 \%$ \\
Slogan (text) & 5 & $2.9 \%$ \\
Total & $\mathbf{1 7 0}$ & $\mathbf{1 0 0}$ \\
\hline
\end{tabular}

The above table indicated colour as an aspect with most impact as illustrated by $80(47 \%)$ of the respondents, followed by background music at 50 (29.4\%), 20 (11.8\%) identified image as an aspect with most impact while only $5(2.9 \%)$ stated text to be what impacts them most. 


\section{CONCLUSION}

The images in all three adverts are objective, meaning the viewer is imposed on what they will see. To achieve the interactional meaning, all the three adverts have participants endorsing the product. They make the viewer feel part of the advertising. The polarised text in the three adverts also helps in achieving the textual function.

\section{REFERENCES}

Barthes. R. (1977). Image music text. London: Fontana Press.

Bateman, J. (2014). Using Multimodal Corpora for Empirical Research. In C. Jewitt (Ed.), Routledge Handbook of Multimodal Analysis (pp. 238-252). London: Routledge.

Cashmore, J. (2008). Children's and Parents' perception of advertising. Journal of foreign languages, 35, 71-74.

Connoly, M. B. (2002). Attention as a cultural problem. In M. B. Crawford (Ed.), the world Beyond Your Head: On Becoming an Individual In An Age of Distraction (pp. 3-27). Farrar: Strausand Giroux.

Cook, G. (2001). The Discourse of Advertising. London: Routledge.

Feng, D., \& O’Halloran, K. (2012). Representing emotion in visual images: A social semiotic approach. Journal of Pragmatics, 44, 20672084.

Forceville, C. (1996). Pictorial Metaphor in Advertising. London: Routledge. http://dx.doi.org/10.4324/9780203272305

Gillespie Y. R. and Halford, R. (2006). Multimodal text analysis: A corpus-based approach to situated discourse. Text and Talk, 26,127-167. http://dx.doi.org/10.1515/TEXT.2006.007

Guolla, W. (2011). On the construction of legal facts in court discourse: A multimodal perspective. Journal of Guangdong University of Foreign Studies, 1, 53-57.
Halliday, M. (1994). An introduction to functional grammar. London: Edward Arnol (Publishers) Limited.

Hassan, S. (2015). Body language in face-to-face teaching. In S. Dreyfus, S. Hood, \& M. Stenglin, (Eds.), Semiotic Margins (pp. 31-52). London: Continuum.

Hazel G. (2007), "Advertising Images: From Persuasion to Polysemy," Journal of Current Issues and Research in Advertising, 1 (Spring), 19-31.

Keller \& Kotler D. (2009). Reading Images Critically. In Dines, G. \& Humez, J.M. Gender, Race and Class in Media. A Text Reader. Thousand Oaks: Sage.

Kelly-Holmes, H. (2005). Advertising as Multilingual Communication. Hampshire: Palgrave.

Kress, G., \& van Leeuwen, T. (2006). Reading images: The grammar of visual design $\left(2^{\text {nd }}\right.$ Ed.). London: Routledge.

Nanjom, S. (2002). Analysing multimodal interaction: A methodological framework. London: Routledge.

Prahald, C., Martin, J. R., \& Unsworth, L. (2013). Reading visual narratives: Image analysis of Children's picture books. London: Equinox.

Rossiter, John R. and Lary Percy (1983), "Visual Communication in Advertising," Information Processing Research in Advertising, Richard Jackson Harris, ed., Hillsdale, New York: Lawrence Erlbaum Associates, Inc., 83-125.

Stenglin, M. (2011). Spaced out: An evolving cartography of a visceral semiotic. In $\mathrm{S}$. Dreyfus, S. Hood, \& M. Stenglin (Eds.), Semiotic Margins (pp. 73-100). London: Continuum.

Suggett, P. (2011). Get to know, and use, AIDA: Attention-Interest-Desire-Action. Retrieved fromhttps://www.thebalancecareers.com/getto-know-and-use-aida-39273 
Ventola, E. (2011). Semiotization processes of space. In K.L. O'Halloran, \& B. Smith (Eds.), Multimodal Studies (pp. 220-238). London: Routledge.

Vestergaard, T., \& Schroder, K. (1985). The language of advertising. Massachusetts: Blackwell Publishers.

Wang, H. (2007). The construal of interactive meaning in multimodal advertising discourse. Journal of Sichuan International Studies University, 6, 31-34.

Wamathai, J. (2015, Dec 14). Kass TV is now available on DStv and GOtv. Retrieved from HapaKenya

https://hapakenya.com/2016/12/14/kass-tv-

now-available-dstv-gotv/

Williamson, J. (1972). Decoding advertisements: Ideology and meaning in advertising. London: Martin Boyars. 